\title{
TINJAUAN YURIDIS TINDAKAN PENYIMPANGAN OLEH DETASEMEN KHUSUS 88 ANTITEROR DI HUBUNGKAN DENGAN UU NO. 15 TAHUN 2003 TENTANG TERORISME
}

\author{
Vidya Novidyanti Charlan \\ Fakultas Hukum, Universitas Islam Bandung, Jl. Tamansari No. 1 Bandung 40116 \\ Email: vidyacharlan@gmail.com
}

\begin{abstract}
Abstrak - dilakukan Densus 88 serta penembakan yang dilakukan terhadap terduga teroris Rizal dan Dayah. Penelitian ini bertujuan untuk memahami dan meneliti lebih lanjut mengenai kewenangan Tim Densus 88 dalam penanggulangan tindak pidana terorisme di Indonesia serta prosedur penanganan kasus tindak pidana terorisme berdasarkan peraturan yang berlaku, pelanggaran oleh Tim densus 88 dan sanksinya. Penelitian ini merupakan penelitian kualitatif dengan menggunakan metode pendekatan yang digunakan dalam penelitian ini adalah yuridis normatif dan bersifat deskriptif analisis yang sumbernya dapat diperoleh dari studi kepustakaan dan studi documenter yaitu berupa data sekunder yang terdiri dari bahan hukum primer, sekunder, dan tersier yang kemudian dianalisis menggunakan metode yuridis kualitatif. Dari hasil penelitian dapat disimpulkan bahwa pada dasarnya Tim Densus 88 mempunyai kewenangan untuk melakukan penangkapan terhadap pihak terduga teroris, namun harus sesuai prosedur yang telah ditentukan oleh Undang-Undang yang berlaku, serta harus mempunyai bukti yang cukup untuk melakukan penangkapan.
\end{abstract}

Kata Kunci: Penyimpangan, Densus 88, Terorisme

\begin{abstract}
This study was conducted based on the death of the alleged terrorist Siyono as a result of the persecution by Special Detachment 88 and the shootings carried out against the alleged terrorist Rizal and Dayah. This study aimed at understanding and further examining the authority of Special Detachment 88 team in dealing with terrorism crimes in Indonesia and procedures for handling terrorism criminal cases based on applicable regulations, violations by Special Detachment 88 team, and its sanctions. This study was a qualitative research using normative juridical and descriptive analysis approach whose sources can be obtained from literature study and documentary study in the form of secondary data consisting of primary, secondary, and tertiary legal materials which were then analyzed using qualitative juridical method. From the results of the study, it can be concluded that Special Detachment 88 team has the authority to make arrests of suspected terrorist parties, but must be following procedures determined by applicable law and must have sufficient evidence to make arrests.
\end{abstract}

Keywords: $\quad$ Deviation, Special Detachment 88, Terrorism

\section{A. PENDAHULUAN}

Indonesia merupakan salah satu Negara yang dianggap memliki ancaman besar, terutama dengan maraknya aksi terror bom di sejumlah tempat. Aksi-aksi terror yang marak terjadi akhir-akhir ini membuat keprihatinan banyak pihak, 
baik masyarakat Nasional dan Internasional. Aksi-aksi terror menyebabkan hilangnya rasa aman ditengah-tengah masyarakat, selain itu juga menurunkan wibawa pemerintah sebagai badan yang seharusnya memberian perlindungan dan rasa aman ditengah-tengah masyarakat. ${ }^{1}$

Terorisme merupakan kejahatan terhadap kemanusiaan dan kejahatan terhadap peradaban yang menjadi ancaman bagi segenap bangsa serta musuh dari semua agama $^{2}$ dan terorisme merupakan kejahatan terhadap kemanusiaan dan salah satu ancaman serius terhadap kedaulatan setiap negara, karena menimbulkan bahaya keamanan, perdamaian dunia serta merugikan kesejahteraan masyarakat sehingga perlu dilakukan pemberantasan secara berencana dan berkesinambungan sehingga hak asasi orang banyak dapat dilindungi dan dijunjung tinggi. Pernyataan tersebut sejalan dengan tujuan bangsa Indonesia dalam Undangundang Dasar 1945 yaitu melindungi segenap bangsa Indonesia dan seluruh tumpah darah Indonesia, dan untuk memajukan kesejahteraan umum, mencerdaskan kehidupan

1 Sukawarsini Djelantik, Tetorisme: Tinjauan Psiko-Politis, Peran Media, Kemiskinan, Dan Keamanan Nasional (Jakarta:Yoi (Yayasan Pustaka Obor Indonesia), 2010), Hlm.1.

${ }^{2}$ Moch. Faisal Salam., Motivasi Tindakan Terorisme, Bandung: Mandar Maju, 2005, hal. 5 . bangsa, dan ikut melaksanakan ketertiban dunia. $^{3}$

Tindakan terorisme pada belakang ini, lebih sering dilakukan dengan cara tindakan peledakan bom yang banyak menelan korban dibanding terorisme melalui cara teror psikis, sekalipun kedua tindakan terorisme merupakan tindakan yang tidak dapat dibenarkan dan menelan korban. Dalam menghadapi ancaman maupun perang melawan terorisme, pemerintah perlu meningkatkan kewaspadaan dengan mengorganisir seluruh kekuatan untuk lebih efektif dan efisien, dan melakukan peningkatan setiap saat serta secara maksimal. Bukan hanya dalam menghadapi ancaman terorisme saja pemerintah harus lebih meningkatkan kewaspadaan, tetapi juga pada penanggulangan dan perlindungan, teutama terhadap korban tindakan terorisme pemerintah berkewajiban untuk memberikan penanggulangan dan perlindungan terorganisir dan secara maksimal, baik kesejahteraan, keamanan maupun secara hukum, karena dengan membantu dan merehabilitasi para korban, memperkecil rasa takut (traumatis) masyarakat disamping meningkatkan kewaspadaan dan partisipasi masyarakat dalam melawan terorisme semakin meningkat.

\footnotetext{
${ }^{3}$ Abdul Wahid, Kejahatan Terorisme Perspektif Agama, Ham Dan Hukum, Refika Aditama, Bandung, 2004, Hlm 1.
} 
Terorisme pada saat sekarang bukan saja merupakan sesuatu kejahatan lokal atau nasional, tetapi sudah merupakan suatu kejahatan transnasional bahkan internasional. Terorisme yang sudah menjadi suatu kejahatan yang bersifat internasional, banyak menimbulkan ancaman atau bahaya terhadap keamanan, perdamaian dan sangat merugikan kesejahteraan masyarakat dan bangsa. ${ }^{4}$

\section{Rangkaian}

peristiwa

pemboman yang terjadi di wilayah negara Republik Indonesia telah menimbulkan rasa takut masyarakat secara luas, mengakibatkan hilangnya nyawa serta kerugian harta benda, sehingga menimbulkan pengaruh yang tidak menguntungkan pada kehidupan sosial, ekonomi, politik, dan hubungan dengan dunia Internasional. Peledakan bom tersebut merupakan salah satu modus pelaku terorisme yang telah menjadi fenomena umum di beberapa Negara. Terorisme merupakan kejahatan lintas Negara, terorganisir, dan bahkan merupakan tindak pidana Internasional yang mempunyai jaringan luas, yang mengancam perdamaian dan keamanan Nasional maupun Internasional. Pemerintah Indonesia sejalan dengan amanat sebagaimana ditentukan dalam Pembukaan Undang-Undang Dasar

\footnotetext{
${ }^{4}$ Mudzakkir, Pengkajian Hukum Tentang Perlindungan Hukum Bagi Korban Terorisme, Badan Pembinaan Hukum Nasional Departemen Hukum Dan Hak Asasi Manusia Ri,Jakarta,2008. Hlm. 6-7 .
}

Negara Republik Indonesia Tahun 1945 yakni melindungi segenap bangsa Indonesia dan seluruh tumpah darah Indonesia, memajukan kesejahteraan umum, mencerdaskan kehidupan bangsa dan ikut serta dalam memelihara ketertiban dunia yang berdasarkan kemerdekaan dan perdamaian abadi dan keadilan sosial, berkewajiban untuk melindungi warganya dari setiap ancaman kejahatan baik bersifat nasional maupun bersifat Internasional. Pemerintah juga berkewajiban untuk mempertahankan kedaulatan serta memelihara keutuhan dan integritas Nasional dari setiap bentuk ancaman baik yang datang dari luar maupun dari dalam. Untuk itu, maka mutlak diperlukan penegakan hukum dan ketertiban secara konsisten dan berkesinambungan. $^{5}$

$$
\text { Upaya yang dilakukan }
$$

Pemerintah dalam memberantas Tindak Pidana Terorisme ialah dengan adanya Peraturan Pemerintah Pengganti Undang-Undang (Perpu) Nomor 1 tahun 2002, yang pada tanggal 4 April 2003 disahkan menjadi Undang-Undang dengan Nomor 15 tahun 2003 tentang Pemberantasan Tindak Pidana Terorisme. Selain itu, UndangUndang Pemberantasan Tindak

\footnotetext{
${ }^{5}$ Penjelasan Undang-Undang Republik Indonesia Nomor 15 Tahun 2003 Tentang Penetapan Peraturan Pemerintah Pengganti Undang-Undang Nomor 1 Tahun 2002 Tentang Pemberantasan Tindak Pidana Terorisme, Menjadi Undang-Undang
} 
Pidana Terorisme perlu dibentuk karena pemerintah menyadari tindak pidana terorisme merupakan suatu tindak pidana yang luar biasa (extraordinary crime), sehingga membutuhkan penanganan yang luar biasa juga (extraordinary measures).

Dalam Undang-Undang No. 15

Tahun 2003 Tentang Terorisme, polisi ditunjuk untuk melakukan penegakan hukum terhadap kejahatan terorisme dalam hal melakukan penangkapan, penahanan, penyelidikan, penyidikan sesuai fungsi kepolisian pada Pasal 2 Undang-undang Kepolisan Negara Nomor 2 tahun $2002^{6}$. Oleh karena itu, dibentuklah satu Detasemen Khusus di bawah Brigadir Mobil (BRIMOB) Kepolisian Republik Indonesia yang disebut Detasemen Khusus 88 selanjutnya disingkat Densus 88 yang tugas utamanya adalah membina dan meyelenggarakan tugas dan fungsi penyelidikan dan penyidikan tindak pidana teroris dalam rangka penegakan hukum ${ }^{7}$.

Densus 88 dibentuk dengan Skep Kapolri No. 30/VI/2003 tertanggal 20 Juni 2003 tentang pembentukan Densus 88 untuk melaksanakan Undang-undang No. 15 Tahun 2003 tentang penetapan

6 Undang-Undang Nomor 2 tahun 2002 tentang Kepolisian Pasal 2

https://id.wikipedia.org/wiki/Detasemen_Kh usus_88_(Anti_Teror) (akses tanggal 28 Juni 2016, jam 13.35)
Perpu No. 1 Tahun 2002 tentang Pemberantasan Tindak Pidana Terorisme.

Detasemen khusus 88 dirancang sebagai unit anti teroris yang memiliki kemampuan mengatasi gangguan teroris mulai dari ancaman bom hingga penyanderaan. Densus 88 di pusat (Mabes Polri) berkekuatan diperkirakan 400 personel ini terdiri dari ahli investigasi, ahli bahan peledak (penjinak bom), dan unit pemukul yang di dalamnya terdapat ahli penembak jitu. Selain itu di masing-masing kepolisian daerah juga memiliki unit anti terror yang disebut Densus 88, kurang lebih berangotakan 45-75 orang. Namun dengan fasilitas dan kemampuan yang lebih terbatas.

Sesuai peraturan mulai dari undang-undang sampai ke peraturan teknis tersebut bertujuan agar Densus 88 menjalankan tugasnya sesuai dengan syarat dan batas-batas yang ditentukan oleh hukum, termasuk terhadap kewenangan diskresi yang dimilikinya, sehingga tidak terjadi penyalahgunaan kewenangan dan kekuasaan yang berpotensi terjadinya pelanggaran HAM.

Dugaan pelangaran HAM oleh Densus 88 dalam menjalankan tugasnya merupakan permasalahan kompleks, karena tidak hanya disebebkan oleh warisan namun militerisme masa lalu yang masih melekat dan alasan karateristik teroris yang berbahaya, tetapi juga 
terkait dengan kelemahan regulasi dan minimnya pemahaman HAM oleh aparat. Masalah regulasi misalnya terlihat dengan adanya perbedaan tentang masa penahan tersangka teroris antara KUHAP dan undang-undang teroris yang rentan dengan adanya penculikan dan penyiksaan tersangka. ${ }^{8}$

Sejalan dengan adanya penembakan mati serta penganiayaan yang telah terjadi belakangan ini yang dilakukan Densus 88, banyak yang tidak setuju dan meminta Densus $\quad 88$ untuk mempertanggungjawabkan

perbuatannya tersebut. Pertanggungjawaban yang akan dikenakan kepada Densus 88 adalah pertanggungjawaban pidana serta kode etik dimana dalam pertanggungjawaban pidana harus adanya unsur dilihat dulu apakah ada unsur kesalahan dan kealphaan yang dilakukan oleh Densus 88 diluar dari penyerangan yang dilakukan oleh tersangka terorisme.

Adanya potensi pelanggaran HAM dalam pemberantasan terorisme oleh Densus 88 harus dicegah seoptimal mungkin melalui pemahaman dan pelaksanaan code of conduct yang diatur dalam berbagai peraturan yang ada, khususnya tentang implementasi prinsip dan standar hak asasi manusia dalam penyelenggaraan tugas Kepolisian Negara Republik Indonesia.

\footnotetext{
${ }^{8}$ Moh Hatta, Kebijakan Politik Kriminal, Pustaka Pelajar, Yogyakarta, 2010
}

Tindak pidana terorisme memang bisa dikategorikan sebagai kejahatan luar biasa, namun dalam penumpasannya harus tetap memperhatikan asas praduga tak bersalah. Dalam kajian hukum pidana ada asas umum yang harus ada terkait hak tersangka dimata hukum termasuk presumption of innocence (Praduga Tak Bersalah), yakni sebelum ada putusan pengadilan seseorang masih dinyatakan tidak bersalah termasuk masih dijunjung Hak Asasi Manusia. $^{9}$

Adanya keharusan untuk memperhatikan asas praduga tak bersalah ini erat kaitannya dengan pemenuhan hak asasi manusia yang dimiliki oleh para tersangka terorisme, terutama hak hidup. Pada kasus- kasus di atas, sebagian besar tersangka terorisme yang ditembak adalah Warga Negara Indonesia yang dijamin hak hidupnya oleh UndangUndang Dasar 1945 pasal 28A yang menyebutkan bahwa; "Setiap orang berhak untuk hidup serta berhak mempertahankan hidup dan kehidupannya."10

Dalam beberapa operasi yang dilakukan oleh Densus 88 dalam menanggulangi tindak terorisme dilakukan tidak sesuai prosedur yang telah ditentukan. Berdasarkan prosedur Densus 88 berwenang menembak mati terduga teroris jika

\footnotetext{
${ }^{9}$ Moeljatno, Asas-Asas Hukum Pidana, Jakarta: Rineka Cipta, 2000.

${ }^{10}$ Undang-Undang Dasar 1945 pasal 28A
} 
ada perlawanan yang membahayakan dirinya, orang lain, dan keamanan. Namun dalam sebuah kasus Densus 88 menembak mati terduga teroris tanpa ada perlawanan atau salah tembak mati sehingga meninggal di tempat tanpa ada suatu proses dan upaya hukum yang dilakukan orang yang disangka tersebut. ${ }^{11}$

Salah satu contoh kasus operasi pemberantasan terorisme yang dipertanyakan dasarnya yaitu Komisi Nasional Hak Asasi Manusia (Komnas HAM) menemukan dugaan adanya pelanggaran HAM oleh tim Detasemen Khusus (Densus) 88 Antiteror dalam kasus penembakan dua terduga teroris jaringan Poso di Kabupaten Tulungagung, Jawa Timur, Senin (22/7). Komisioner Komnas HAM Siane Indriani, setelah melakukan investigasi di Kabupaten Tulungagung dan Lamongan, Minggu (4/8), menyatakan pihaknya menemukan fakta Densus 88 Antiteror menembak dua terduga teroris saat dalam kondisi tidak berdaya.

Dalam kasus tersebut Komnas HAM menemukan adanya kejanggalan terhadap proses penembakan mati terhadap dua terduga teroris $\mathrm{M}$ Hidayah atau Dayah alias Kim dan Rizal atau Eko di Jalan Pahlawan, Kota Tulungagung pada 22 Juli 2013 oleh

${ }^{11}$ Wibowo, Ari, Kebijakan Formulatif Pidana dalam penanggulangan Tindak Pidana Terorisme di Indonesia, Yogyakarta: Graha Ilmu, 2012.
10 personel Densus 88 Antiteror. Komnas HAM menemukan fakta dua terduga teroris tersebut ditembak dalam kondisi tidak berdaya dan tidak ada perlawanan.

Saat kejadian, Rizal dan Dayah baru turun dari motor boncengansepeda motor Sapari dan Mugi Hartanto di sebuah halte di jalan Pahlawan, Kota Tulungagung, mereka membawa dua kardus mi instan berisi pakaian dan buku-buku milik Rizal. Namun baru beberapa saat berdiri di pinggir trotoar halte bus, tiba-tiba mereka diserang oleh sekitar sepuluh personel Densus 88 berpakaian preman yang muncul dari dua mobil. Para anggota Densus langsung menghamburkan tembakan ke arah Rizal dan Dayah. ${ }^{12}$

Dari kasus tersebut tentunya terdapat pelanggaran penggunaan senjata api, dimana dalam Pasal 8 ayat (2) Perkapolri No. 1 Tahun 2009 tentang penggunaan kekuatan dalam tindakan kepolisian disebutkan bahwa "penggunaan senjata api merupakan upaya terakhir untuk menghentikan pelaku kejahatan atau tersangka". Serta ketentuan mengenai penembakan hanya dilakukan apabila tersangka terorisme melakukan perlawanan.

Selain itu adanya kasus siyono yang merupakan terduga teroris, dimana Komisioner Komnas HAM

\footnotetext{
${ }^{12}$ http://microsite.metrotvnews.com/indonesi amemilih/read/Komnas-HAM-DugaPenembakan-Teroris-di-TulungagungLanggar-HAM (Akes tanggal 10 Januari 2016, pkul 20.00)
} 
Siane Indriani mengungkapkan bahwa; "Kematian Siyono adalah akibat dari tulang dada patah ke arah jantung sehingga mengakibatkan kematian. Ada luka di kepala tapi tidak menyebabkan kematian. Tidak ditemukan adanya perlawanan dari almarhum karena tidak ada luka defensif," kata dia. Siane juga menyebutkan bahwa hasil autopsi menunjukkan ada memar pada bagian tubuh belakang, analisisnya ada indikasi tindak kekerasan yang dilakukan ketika korban sedang menyandar ke sesuatu. ${ }^{13}$ Hal tersebut menunjukkan bahwa adanya penganiayaan yang menyebabkan kematian yang dilakukan kepada terduga terorisme siyono yang tentunya bertentangan dengan SOP (Prosedur Penindakan Tersangka Tindak Pidana Terorisme) yang dikeluarkan dalam bentuk Peraturan Kapolri

Nomor: PERKAP/23/XI/2011, pada BAB IV (Prosedur Penindakan) Pasal 19 ayat (3) menyebutkan bahwa: "Penindakan yang menyebabkan matinya seseorang/tersangka harus dapat dipertanggungjawabkan secara hukum."

${ }^{13}$ Deasy Mayasari, Proses Selesai, Hasil Autopsi Siyono Dipublikasikan, Times Indonesia, 2016, Diakses dari: http://www.timesindonesia.co.id/baca/1230 50/20160411/144651/proses-selesai-hasilautopsi-siyono-dipublikasikan/, Diakses Pada tanggal 7 juli 2016.
Dari permasalahan tersebut, penulis ingin mengkaji lebih dalam mengenai bagaimana kewenangan densus 88 dalam melakukan penanganan kejahatan terorisme serta sanksi apabila terjadi penyimpangan dalam pelaksanaan penanganan kejahatan terorisme tersebut. Hal inilah yang akan diangkat oleh penulis dalam tesis yang berjudul "TINJAUAN YURIDIS TINDAKAN PENYIMPANGAN OLEH DETASEMEN KHUSUS 88 ANTITEROR DALAM HAL PENANGANAN PELAKU KEJAHATAN TERORISME DI HUBUNGKAN DENGAN UNDANG-UNDANG NOMOR 15 TAHUN 2003 TENTANG TERORISME".

\section{B. Identifikasi Masalah}

Bertumpu dari latar belakang di atas maka permasalahan yang diangkat dalam penulisan ini adalah sebagai berikut:

1. Bagaimanakah kewenangan tim densus 88 dalam penanggulangan tindak pidana terorisme di Indonesia dihubungkan dengan undangundang Nomor 15 Tahun 2003?

2. Bagaimanakah Prosedur penanganan kasus tindak pidana terorisme serta sanksi terhadap detasemen khusus 88 antiteror dalam hal terjadi penyimpangan penanganan pelaku kejahatan terorisme di hubungkan dengan 
undang-undang nomor 15 tahun 2003 tentang terorisme.

\section{Tujuan Penelitian}

Secara umum tujuan penulisan adalah untuk mendalami aspek tentang permasalahan-permasalahan yang telah dirumuskan dalam perumusan masalah. Secara khusus tujuan penulisan ini dapat dirumuskan sebagai berikut:

1. Untuk mengetahui kewenangan Densus 88 yang khusus menangani kasus Tindak pidana terorisme di Indonesia.

2. Untuk mengetahui dan memahami Prosedur penanganan kasus tindak pidana terorisme serta sanksi terhadap detasemen

3. Khusus 88 antiteror dalam hal terjadi penyimpangan penanganan pelaku kejahatan terorisme di hubungkan dengan undang-undang nomor 15 tahun 2003 tentang terorisme.

\section{METODE PENELITIAN}

Metode pendekatan yang digunakan dalam penelitian ini adalah yuridis normatif dan bersifat deskriptif analisis yang sumbernya dapat diperoleh dari bahan pustaka dan studi dokumen, hasil yang diperoleh dianalisis dengan menggunakan metode normatif kualitatif sehingga tidak menggunakan rumus matematis maupun statistik.

E. PEMBAHASAN

\section{Prosedur Penanganan Kasus Tindak Pidana Terorisme}

Kasus terorisme tergolong dalam kategori tindak pidana khusus, sebagaimana sifat dari hukum itu sendiri bahwa menciptakan suatu sistem yang struktural harus diutamakan berfungsinya unsur legalitas yang menjadi dasar peletakan sanksi, menghilangkan resiko korban dan lain-lain dari pembatasan formal dalam proses hukum pidana dan hukum acara pidana pada dasarnya mengikuti ketentuan yang menjadi esensi utama dari ketentuan hukum pidana dan hukum acara pidana sebagai penjelasan yang konkrit dari pasal demi pasal yang terdapat dalam kitab undang hukum pidana itu sendiri.

Dimulainya perumusan UU No.15 tahun 2003 tentang pemberantasan tindak pidana terorisme di Indonesia terjadi babak pencerahan bagi sistem hukum di Indonesia yang mengkhususkan ketentuan dasar sebagai ketentuan Hukum Acara Pidana Terorisme yang persuasif dan kondusif. Kedudukan UU No.15 tahun 2003 tentang pemberantasan tindak pidana terorisme yang telah mencapai prosesi legalitas, kemudian mendudukan asas-asas Hukum acara pidana semakin prospektif.

$$
\text { Ketentuan peradilan }
$$
terorisme dengan adanya UU No.15 tahun 2003 tentang pemberantasan tindak pidana terorisme adalah menjadi Hukum acara pidana 
terorisme yang diposisikan sebagai ketentuan asas lex spesialis derogat, lex spesialis general. Dengan demikian, penerjemahan UU No.15 tahun 2003 menjadi bagian pokok Hukum Acara Pidana mengenai Terorisme yang positif.

Undang-undang No. 1 Tahun 2002 tentang Pemberantasan Tindak Terorisme tersebut disahkan karena menyadari sedemikian besarnya kerugian yang ditimbulkan oleh suatu tindak terorisme, serta dampak yang dirasakan secara langsung oleh Indonesia.

Pada dasarnya pengaturan mengenai prosedur penanganan dan penindakan tersangka terorisme diatur dalam Peraturan Kepala Kepolisian Negara Republik Indonesia Nomor 23 Tahun 2011 Tentang Prosedur Penindakan Tersangka Tindak Pidana Terorisme pada BAB III Pasal 9 yang menyebutkan bahwa:

Kegiatan pra-penindakan merupakan kegiatan awal untuk:
a) Menyusun
perencanaan penindakan;
b) Menyiapkan administrasi penyidikan antara lain:

1) Surat perintah penangkapan;
2) Surat perintah penggeledahan;
c) Menentukan kebutuhan personel, peralatan, dan anggaran;

d) Memperhitungkan situasi dan kondisi di lokasi penindakan; e) Mempersiapkan kegiatan paska penindakan.

Selain itu juga diatur dalam Peraturan Kepala Kepolisian Negara Republik Indonesia Nomor 8 Tahun 2009 Tentang Implementasi Prinsip Dan Standar Hak Asasi Manusia Dalam Penyelenggaraan Tugas Kepolisian Negara Republik Indonesia pada Bab III Pasal 10 yang menyebutkan bahwa: "Dalam melaksanakan tugas penegakan hukum, setiap petugas/anggota Polri wajib mematuhi ketentuan berperilaku (Code of Conduct) sebagaimana dimaksud dalam Pasal 7 huruf h sebagai berikut:

a. Senantiasa menjalankan tugas yang diamanatkan oleh undangundang kepada mereka;

b. Menghormati dan melindungi martabat manusia dalam melaksanakan tugasnya tidak boleh menggunakan kekerasan, kecuali dibutuhkan untuk mencegah kejahatan membantu melakukan penangkapan terhadap pelanggar hukum atau tersangka sesuai dengan peraturan penggunaan kekerasan;

c. Hal-hal yang bersifat rahasia yang berada dalam kewenangan harus tetap dijaga kerahasiaannya, kecuali jika diperlukan dalam pelaksanaan tugas atau untuk kepentingan peradilan;

d. Tidak boleh menghasut, mentolerir tindakan penyiksaan, 
perlakuan atau hukuman lain yang kejam, tidak manusiawi atau merendahkan martabat manusia, demikian pula menjadikan perintah atasan atau keadaan luar biasa seperti ketika dalam keadaan perang sebagai pembenaran untuk melakukan penyiksaan;

e. Menjamin perlindungan sepenuhnya terhadap kesehatan orang-orang yang berada dalam tahanannya, lebih khusus lagi, harus segera mengambil langkah untuk memberikan pelayanan medis bilamana diperlukan;

f. Tidak boleh melakukan korupsi dalam bentuk apapun, maupun penyalahgunaan kekuasaan lainnya yang bertentangan dengan profesi penegak hukum;

g. Harus menghormati hukum, ketentuan berperilaku, dan kode etik yang ada.

Pasal 11 juga menyebutkan bahwa:

1) Setiap petugas/anggota Polri dilarang melakukan:
a) Penangkapan
dan
penahanan
secara
sewenang-wenang dan tidak
berdasarkan hukum;
b) Penyiksaan tahanan atau terhadap orang yang disangka terlibat dalam kejahatan;
c) Pelecehan atau kekerasan seksual terhadap tahanan atau orang-orang yang disangka terlibat dalam kejahatan;
d) Penghukuman dan/atau perlakuan tidak manusiawi yang merendahkan martabat manusia;
e) Korupsi dan menerima suap;

f) Menghalangi proses peradilan dan/atau menutupnutupi kejahatan;

g) Penghukuman dan tindakan fisik yang tidak berdasarkan hukum (corporal punishment);

h) Perlakuan tidak manusiawi terhadap seseorang yang melaporkan kasus pelanggaran HAM oleh orang lain;

i) Melakukan penggeledahan dan/atau penyitaan yang tidak berdasarkan hukum;

j) Menggunakan kekerasan dan/atau senjata api yang berlebihan.

2) Anggota Polri yang melakukan tindakan melanggar HAM wajib mempertanggungjawabkan sesuai dengan kode etik profesi kepolisian, disiplin dan hukum yang berlaku.

Selain itu Pasal 13 juga menyebutkan bahwa:

1) Dalam melaksanakan kegiatan penyelidikan, setiap petugas Polri dilarang:
a) Melakukan intimidasi, ancaman, siksaan fisik, psikis ataupun seksual untuk mendapatkan informasi, keterangan atau pengakuan; 
b) Menyuruh atau menghasut orang lain untuk melakukan tindakan kekerasan di luar proses hukum atau secara sewenang-wenang;

c) Memberitakan rahasia seseorang yang berperkara;

d) Memanipulasi atau berbohong dalam membuat atau menyampaikan laporan hasil penyelidikan;

e) Merekayasa laporan sehingga mengaburkan investigasi atau memutarbalikkan kebenaran;

f) Melakukan tindakan yang bertujuan untuk meminta imbalan dari pihak yang berperkara.

Pada intinya, prosedur penanganan kasus tindak pidana terorisme telah diatur secara spesifik dalam aturan-aturan tersebut diatas, selain itu dalam hal pelaksanaan penanganan tindak pidana terorisme diatur mengenai penggunaan senjata yang diatur dalam Pasal 8 ayat (2) Perkapolri No. 1 Tahun 2009 tentang penggunaan kekuatan dalam tindakan kepolisian juga menyebutkan bahwa "penggunaan senjata api merupakan upaya terakhir untuk menghentikan pelaku kejahatan atau tersangka".

\section{Analisis Pelanggaran Densus 88 Serta Sanksi Yang Diberikan}

Berdasarkan uraian mengenai prosedur penanganan tindak pidana terorisme tersebut diatas, dimana pelaksanaan penanganan tindak pidana terorisme tentunya harus sesuai dengan peraturan tersebut, sehingga apabila dikaitkan dengan kasus Siyono dan Kasus Rizal serta Dayah, maka tentunya Densus 88 dalam hal ini telah melanggar prosedur tersebut.

Dalam kasus Siyono dua anggota Densus 88 itu diduga melanggar Pasal 7 ayat 1 dan 2 yang intinya bahwa setiap anggota Polri wajib meningkatkan citra, soliditas, dan integritas anggotanya. Keduanya juga dituntut Pasal 13 huruf a kode etik yang isinya menyebutkan bahwa "Setiap anggota Polri sebagai atasan dilarang memberi perintah bertentangan dengan norma hukum. Kan anggota ini ada yang atasan dan bawahannya".

Selain itu bila dilihat dalam Peraturan Kepala Kepolisian Negara Republik Indonesia Nomor 8 Tahun 2009 Tentang Implementasi Prinsip Dan Standar Hak Asasi Manusia Dalam Penyelenggaraan Tugas Kepolisian Negara Republik Indonesia pada Bab III Pasal 10 yang pada intinya menyebutkan bahwa: " Dalam melaksanakan tugas penegakan hukum, setiap petugas/anggota Polri wajib mematuhi ketentuan berperilaku (Code of Conduct) sebagaimana dimaksud dalam Pasal 7 huruf $\mathrm{h}$ sebagai berikut: (h) tidak boleh menghasut, mentolerir tindakan penyiksaan, perlakuan atau hukuman 
lain yang kejam, tidak manusiawi atau merendahkan martabat manusia, demikian pula menjadikan perintah atasan atau keadaan luar biasa seperti ketika dalam keadaan perang sebagai pembenaran untuk melakukan penyiksaan; (i) menjamin perlindungan sepenuhnya terhadap kesehatan orang-orang yang berada dalam tahanannya, lebih khusus lagi, harus segera mengambil langkah untuk memberikan pelayanan medis bilamana diperlukan."

$$
\text { Dalam kasus Siyono, }
$$
berdasarkan fakta-fakta yang ada dimana pada jenazahnya terdapat bekas luka serta memar-memar ditubuhnya, yang memungkinkan adanya penyiksaan yang dilakukan terhadap Terduga Siyono tersebut, sehingga dalam hal ini Densus 88 tidak mematuhi atau dalam artian melanggar ketentuan yang ada dalam Pasal tersebut diatas.

Selain itu dalam peraturan yang sama Pasal 11 juga menyebutkan bahwa: "Setiap petugas/anggota Polri dilarang melakukan: (a) penangkapan dan penahanan secara sewenang-wenang dan tidak berdasarkan hukum; (b) penyiksaan tahanan atau terhadap orang yang disangka terlibat dalam kejahatan; (i) melakukan penggeledahan dan/atau penyitaan yang tidak berdasarkan hukum."

Berdasarkan fakta dilapangan, penangkapan yang dilakukan oleh Densus 88 dilakukan secara sewenang-wenang, dimana dalam melakukan penangkapan dan penahanan tersebut, Densus 88 belum mempunyai bukti yang kuat sebagai dasar dilakukannya penangkapan, serta tindakan penggeledahan yang dilakukan tidak mempunyai dasar hukum dimana pada saat penggeladahan dilakukan Densus 88 tidak menunjukkan surat penggeladahan yang seharusnya ditandatangani oleh keluarga Siyono, dan pada saat tersebut petugas Densus 88 langsung mengambil sepeda motor milik Terduga Siyono tanpa dasar. Hal tersebut merupakan tindakan sewenang-wenang yang tentunya melanggar peraturan yang berlaku.

Adapun sanksi yang dituntut kepada dua anggota Densus 88 adalah kewajiban bagi para pelanggar untuk menyatakan permohonan maaf atas kekeliruan mereka kepada institusi Polri dan masyarakat. Sanksi lain yang juga diusulkan adalah pemberhentian dengan tidak hormat. Selain itu, ada pula opsi untuk memutasikan dua anggota tersebut ke satuan lain. Majelis etik memberi kesempatan kepada dua anggota Densus 88 yang diperiksa untuk menyusun pembelaan. Dengan demikian, majelis akan menimbang hal yang meringankan dan memberatkan.

Adapun kasus Rizal dan Dayah yang telah dijelaskan sebelumnya tentunya terdapat pelanggaran penggunaan senjata api, dimana dalam Pasal 8 ayat (2) Perkapolri No. 
1 Tahun 2009 tentang penggunaan kekuatan dalam tindakan kepolisian disebutkan bahwa "penggunaan senjata api merupakan upaya terakhir untuk menghentikan pelaku kejahatan atau tersangka". Serta ketentuan mengenai penembakan hanya dilakukan apabila tersangka terorisme melakukan perlawanan.

Dalam hal ini Rizal dan Dayah pada saat penangkapan tidak melakukan perlawanan sama sekali, bahkan tidak memegang senjata api pada saat kejadian. Sehingga dalam hal ini tentunya Densus 88 tidak mematuhi peraturan tersebut dan harus mendapat sanksi atas perbuatannya.

Terkait dengan kasus-kasus tersebut kita lihat dalam UU Nomor 15 Tahun 2003 tentang Pemberantasan Tindak Pidana Terorisme. Pasal 28 menyebutkan bahwa penyidik dapat melakukan penangkapan terhadap setiap orang yang diduga keras melakukan tindak pidana terorisme berdasarkan bukti permulaan yang cukup sebagaimana dimaksud dalam Pasal 26 Ayat (2) untuk paling lama 7 x 24 jam.Status aparat Densus 88 yang melakukan penangkapan seharusnya sebagai penyidik, bukan hanya pasukan pemukul.Kecuali, jika terduga terorisme bersenjata.

Selain itu, Pasal 17 Kitab Undang-Undang Hukum Acara Pidana/KUHAP, juga menyebutkan bahwa perintah Penangkapan hanya dapat dilakukan terhadap seseorang yang diduga keras telah melakukan Tindak Pidana berdasarkan Bukti Permulaan yang cukup.

Dalam hal ini Densus 88 belum mempunyai bukti-bukti yang kuat untuk melakukan penangkapan, apalagi menggunakan senjata api terhadap pihak yang masih berstatus sebagai terduga teroris. Hal yang kemudian menjadi sorotan adalah bahwa apakah yang dimaksud dengan bukti permulaan yang cukup, apakah pemilikan senjata dan bahan peledak, atau sekadar rencana aksi teror atau komunikasi dengan pelaku teror sebelumnya. Informasi intelijen tentang bukti itu sering belum cukup. Hal tersebutlah yang bias menyebabkan Densus 88 salah tangkap, bahkan salah tembak yang menyebabkan kematian seperti kasus di atas.

Mengenai batasan dari pengertian Bukti Permulaan itu sendiri, hingga kini belum ada ketentuan yang secara jelas mendefinisikannya dalam Kitab Undang-Undang Hukum Acara Pidana (KUHAP) yang menjadi dasar pelaksanaan Hukum Pidana. Masih terdapat perbedaan pendapat di antara para penegak hukum. Sedangkan mengenai Bukti Permulaan dalam pengaturannya pada Undang-Undang Nomor 15 Tahun 2003 tentang Pemberantasan Tindak Pidana Terorisme, pasal 26 berbunyi:

1) Untuk memperoleh Bukti Permulaan yang cukup, penyidik 
dapat menggunakan setiap Laporan Intelijen.

2) Penetapan bahwa sudah dapat atau diperoleh Bukti Permulaan yang cukup sebagaimana dimaksud dalam ayat (1) harus dilakukan proses pemeriksaan oleh Ketua dan Wakil Ketua Pengadilan Negeri.

3) Proses pemeriksaan sebagaimana dimaksud dalam ayat (2) dilaksanakan secara tertutup dalam waktu paling lama 3 (tiga) hari.

4) Jika dalam pemeriksaan sebagaimana dimaksud dalam ayat (2) ditetapkan adanya Bukti Permulaan yang cukup, maka Ketua Pengadilan Negeri segera memerintahkan dilaksanakan Penyidikan.

Permasalahannya adalah masih terdapat kesimpang siuran tentang pengertian Bukti Permulaan itu sendiri, sehingga sulit menentukan apakah yang dapat dikategorikan sebagai Bukti Permulaan, termasuk pula Laporan Intelijen, apakah dapat dijadikan Bukti Permulaan. Selanjutnya, menurut pasal 26 ayat 2, 3 dan 4 Undang-Undang Nomor 15 tahun 2003 tentang Pemberantasan Tindak Pidana Terorisme, penetapan suatu Laporan Intelijen sebagai Bukti Permulaan dilakukan oleh Ketua/Wakil Ketua Pengadilan Negeri melalui suatu proses/mekanisme pemeriksaan (Hearing) secara tertutup.
Hal itu mengakibatkan pihak intelijen mempunyai dasar hukum yang kuat untuk melakukan penangkapan terhadap seseorang yang dianggap melakukan suatu Tindak Pidana Terorisme, tanpa adanya pengawasan masyarakat atau pihak lain mana pun. Padahal kontrol sosial sangat dibutuhkan terutama dalam hal-hal yang sangat sensitif seperti perlindungan terhadap hakhak setiap orang sebagai manusia yang sifatnya asasi, tidak dapat diganggu gugat. Oleh karena itu, untuk mencegah kesewenangwenangan dan ketidakpastian hukum, diperlukan adanya ketentuan yang pasti mengenai pengertian Bukti Permulaan dan batasan mengenai Laporan Intelijen, apa saja yang dapat dimasukkan ke dalam kategori Laporan Intelijen, serta bagaimana sebenarnya hakekat Laporan Intelijen, sehingga dapat digunakan sebagai Bukti Permulaan.

Terutama karena ketentuan pasal 26 ayat (1) tersebut memberikan wewenang yang begitu luas kepada penyidik untuk melakukan perampasan kemerdekaan yaitu penangkapan, terhadap orang yang dicurigai telah melakukan Tindak Pidana Terorisme, maka kejelasan mengenai hal tersebut sangatlah diperlukan agar tidak terjadi pelanggaran terhadap Hak Asasi Manusia dengan dilakukannya penangkapan secara sewenangwenang oleh aparat, dalam hal ini penyidik. 
Regulasi juga mengatur tentang rehabilitasi status terduga bila Densus 88 melakukan kesalahan karena informasi yang dipegang keliru.Rehabilitasi penting untuk terduga terorisme beserta keluarganya, karena persepsi negatif masyarakat merupakan hukuman tersendiri yang harus dihindari.

Sehingga dalam hal ini, menurut penulis perlu pengaturan yang lebih jelas mengenai bukti permulaan sebagai dasar untuk melakukan penangkapan pihak yang masih berstatus terduga, serta perlu pengawasan yang lebih kepada Densus 88 dalam melakukan pelaksanaan penanganan tindak pidana terorisme agar pelaksanaannya sesuai dengan peraturan yang berlaku dan tidak melakukan tindakan yang sewenangwenang terhadap pihak yang masih berstatus terduga mengingat adanya asas praduga tidak bersalah yang harus diterapkan dan dilindungi agar tetap menjaga hak asasi manusia terduga teroris tersebut.

\section{F. PENUTUP}

\section{Kesimpulan}

Dari uraian pada bab-bab sebelumny dapat disimpulkan sebagai berikut:

1. Kewenangan Tim Densus 88 dalam penanggulangan tindak pidana terorisme di Indonesia pada dasarnya telah diatur dalam Undang-Undang Nomor 2
Tahun 2002 serta UndangUndang Nomor 15 Tahun 2003. Dimana dalam Pasal 13 dan 14 secara umum dijelaskan mengenai kewenangan dari polisi itu sendiri. Densus 88 sebagai satuan khusus Kepolisian Negara Republik Indonesia yang khusus bergerak di bidang pemberantasan tindak pidana terorisme memiliki wewenang yang sama dengan anggota kepolisian lainnya seperti pada Pasal 16 Ayat 1 diatas kewenangan melakukan penangkapan, penahanan, penggeledaan, dan penyitaan ataupun melarang setiap orang meninggalkan atau memasuki tempat kejadian perkara untuk kepentingan penyidikan. Dalam kasus Siyono serta Rizal dan Dayah, dasarnya tim Densus 88 mempunyai kewenangan untuk melakukan penangkapan sebagaimana yang diberikan oleh undang-undang. Namun dalam melaksankan kewenangannya tersebut terdapat kesalahan prosedur yang dilakukan oleh Densus 88.

2. Prosedur penanganan kasus tindak pidana terorisme pada dasarnya diatur dalam Perkapolri Nomor 23 Tahun 2011 Tentang Prosedur Penindakan Tersangka Tindak Pidana Terorisme, serta Perkapolri Nomor 8 Tahun 2009 Tentang Implementasi Prinsip Dan Standar HAM Dalam 
Penyelenggaraan Tugas

Kepolisian Negara Republik Indonesia. Dalam kasus Siyono, bila dilihat dalam Perkapolri Nomor 8 Tahun 2009 pada Bab III Pasal Pasal 10 dan 11 juga menyebutkan bahwa: "Setiap petugas/anggota Polri dilarang melakukan: (a) penangkapan dan penahanan secara sewenangwenang dan tidak berdasarkan hukum; (b) penyiksaan tahanan atau terhadap orang yang disangka terlibat dalam kejahatan; (i) melakukan penggeledahan dan/atau penyitaan yang tidak berdasarkan hukum." Tentunya terdapat pelanggaran Pasal tersebut dalam prosedur penangkapan Siyono.

Adapun dalam kasus Rizal dan Dayah terdapat pelanggaran penggunaan senjata api, dimana dalam Pasal 8 ayat

Perkapolri No. 1 Tahun 2009 tentang penggunaan kekuatan dalam tindakan kepolisian disebutkan bahwa "penggunaan senjata api merupakan upaya terakhir untuk menghentikan pelaku kejahatan atau tersangka”. Dalam hal ini Rizal dan Dayah pada saat penangkapan tidak melakukan perlawanan sama sekali. Adapun sanksi yang dituntut kepada anggota Densus 88 adalah kewajiban bagi para pelanggar untuk menyatakan permohonan maaf atas kekeliruan mereka kepada institusi Polri dan masyarakat. Sanksi lain yang juga diusulkan adalah pemberhentian dengan tidak hormat. Selain itu, ada pula opsi untuk memutasikan dua anggota tersebut kesatuan lain.

\section{Saran}

1. PelaksanaanUndang-Undang Terorisme ini tidak boleh bertentangan dengan asas umum Hukum Pidana dan Hukum Acara Pidana yang telah ada. Meskipun, pada kenyataannya terdapat isi ketentuan beberapa pasal dalam Undang-Undang tersebut yang merupakan penyimpangan asas umum Hukum Pidana dan Hukum Acara Pidana. Penyimpangan tersebut mengurangi HAM, apabila dibandingkan asas-asas yang terdapat dalam KUHP. Sehingga menurut pendapat penulis perlu diatur lebih lanjut mengenai dasar penyimpangan tersebut.

2. Pasal 17 Kitab KUHAP, menyebutkan bahwa perintah Penangkapan hanya dapat dilakukan terhadap seseorang yang diduga keras telah melakukan Tindak Pidana berdasarkan Bukti Permulaan yang cukup. Mengenai batasan dari pengertian Bukti Permulaan itus endiri, hingga kini belum ada ketentuan yang secara jelas 
mendefinisikannya KUHAP yang menjadi dasar pelaksanaan Hukum Pidana. Sehingga menurut pendapat penulis perlu pengaturan lebih lanjut mengenai bukti permulaan sebagai dasar dilakukannya penangkapan.

\section{DAFTAR PUSTAKA}

Abdul Wahid, Kejahatan Terorisme Perspektif Agama, HAM dan Hukum, Refika Aditama, Bandung, 2004

Moch. Faisal Salam., Motivasi Tindakan Terorisme, Bandung: Mandar Maju, 2005

Moh Hatta, Kebijakan Politik Kriminal: Penegakan Hukum Dalam Rangka Penanggulangan Kejahatan, Pustaka Pelajar, Yogyakarta, 2010.

Mudzakkir, Pengkajian Hukum tentang Perlindungan Hukum bagi korban Terorisme, Badan Pembinaan Hukum Nasional Departemen Hukum dan Hak Asasi Manusia RI, Jakarta, 2008. Moeljatno, Asas-Asas Hukum Pidana, Jakarta: Rineka Cipta, 2000.

Sukawarsini Djelantik, Tetorisme:

Tinjauan Psiko-Politis, Peran Media, Kemiskinan, Dan Keamanan Nasional (Jakarta:YOI (Yayasan Pustaka Obor Indonesia), 2010.

Wibowo, Ari, Kebijakan Formulatif Pidana dalam penanggulangan Tindak Pidana Terorisme di
Indonesia, Yogyakarta: GrahaIlmu, 2012.

Undang-Undang Dasar 1945 Kitab undang-undang hukum pidana Kitab Undang-undang Hukum Acara Pidana, cetakan ke-1, Ghalia Indonesia, Jakarta, 1981.

Undang-UndangNomor 2 tahun 2002 tentang Kepolisian Peraturan Kapolri Nomor: PERKAP/23/XI/2011

Undang-Undang Nomor 15 tahun 2003 tentang pemberantasan tindak pidana terorisme

Pasal 1 angka 1 PERPU No. 1 Tahun 2002 Jo UU No. 15 Tahun 2003 tentang Pemberantasan Tindak Pidana Terorisme

Undang-Undang Nomor 39 tahun 1999 Tentang Hak Asasi Manusia Universal Declaration Of Human Rights (1984,art.5)

Pasal 15 Ayat 1, UndangUndangNomor 2 Tahun 2002

Pasal 16 Ayat 1, UndangUndangNomor 2 Tahun 2002, TentangKepolisian Negara Republik Indonesia.

Pasal 16 Ayat 1 Huruf 1, UndangUndangNomor 2 Tahun 2002 tentangKepolisian Negara Republik Indonesia.

Pasal 18 Ayat (1), UndangUndangNomor 2 Tahun 2002 tentang Kepolisian Negara Republik Indonesia.

http://microsite.metrotvnews.com/ind onesiamemilih/read/2013/08/04/ 87/173108/Komnas-HAM- 
Duga-Penembakan-Teroris-di-

Tulungagung-Langgar-HAM

https://id.wikipedia.org/wiki/Detase

men_Khusus_88_\%28Anti_Tero

$\mathrm{r} \% 29$

m.tempo.com//2014/01/3/Temba

$\mathrm{k}$-Terduga-Teroris-di tempat-

Kapolridikritik

Muladi, "BelumMencakupState

Terrorism", www.sijoripos.com.
Kompas, 2 November 2001. Patra M.

Zen, "Terorisme: Standard

HukumInternasional",

www.hukumonline.com.

Muradi Densus 88 AT; Konflik, teror, dan Politik Bantuan luar negeri bukan berupa uang, Republika online

Rekappersonil, polri.go.id , (diunduh 12 Juli 2016 Pukul 18.40 WIB) 